\title{
HISTORICAL VIEW ON SOCIAL EVILS AND PRACTICES ON THE SOCIETY
}

\section{B. MEHARUNNISHA}

Assistant Professor of History, Thiru.Vi.Ka.Govt Arts College, Tiruvarur, Tamilnadu, India

Received: Aug 01, 2021; Accepted: Aug 20, 2021; Published: Sep 09, 2021; Paper Id.: IJHRDEC20215

\section{INTRODUCTION}

The newly educated male elite were thereby products of the new system of English education, though some came from traditional system. The issue which attracted the social reformers was Sati, the ill-treatment of widows and the ban on widow remarriage, polygamy, child marriage and denial of property rights and education of women. Accepting women's status whining the family as an index of their own progress and modernity, the earlier reformers criticized particularly inhuman practices like widow immolation (sati), marriage of child brides to much older men, ban on remarriage of widows, sought to promote some form of education for women.

Social reformers felt that the social evils should be eradicated by raising consciousness and making people sensitive to the injustices perpetuated on women. They felt that by giving women access to education and by enacting progressive legislation, social change could be initiated. While the reformers were concerned with the oppressed conditions of women and wanted to improve their lot through legislation and arousing social conscience, their objectives did not include any conception of equality in the roles between men and women. They saw women as custodians of the family and responsible for the well being of children and for impacting values of Indian culture and civilization and social change could be initiated. The reformers were concerned with the oppressed conditions of women and advocated reinstalling them on their honoured seat of ancient glory and splendor through legislation and arousing social conscience. They demanded the restoration of healthy and congenial conditions as exited in the early Vedic period. Thus the renaissance of Indian women attempted by social reformers exerted upon the democratization of social relations and removal of harmful practices on the basis of revival of Vedic society which was considered to be truly democratic. 


\section{Female Infanticide}

One of the social evils that women had to face in those days was female infanticide. Birth of a female child was not welcome even by parents and they were exposed to death. According to tradition, son the heir apparent is the only person who is the saviour of the parents. He performs the last rites to his parents without which it is believed that parents have no salvation (cannot go to heaven). Further, the husband and the wife have no right to perform a number of religious ceremonies if they are childless. So if they have no son, it is customary to adopt a boy who would make them eligible for performing many rites. Thus, son is a 'must' in the Hindu family. On the other hand birth of a girl is largely looked down upon even now. Tod writes that Rajputs were often heard to explain "accursed the day when a girl child was born". Even though we do not have categorical evidence of female infanticide in Andhra, birth of a girl child does not receive spontaneous welcome in several families even today.

The rise in sex selective abortions and emergence of female infanticide in various parts of the country are two major reasons for excess female child mortality. Incidence of parental selection has rapidly increased in the last decade or so in India. Work on female infanticide in Tamil Nadu shows that this practice has reappeared among certain communities and emerged among some others who did not practice it earlier.

The prevalence of Female infanticide is an indication of the poor status of women. In Tamil Nadu, this practice is reported to be common among both rural and urban areas. Women are pressurized to kill their babies because of their economic circumstances. Many of them, who practice female infanticide, live in poverty. They are either landless laborers or marginal farmer.

Section 315 bof the Indian Penal Code defines infanticide as the killing of an infant in the 0 - 1 year age group. The code uses this definition to differentiate between infanticide and numerous other crimes against children, such as foeticide and murder. Some scholarly publications on infanticide use the legal definition.

\section{Female Infanticide Deaths in Tamil Nadu}

Table 1

\begin{tabular}{|c|l|c|c|c|}
\hline S.NO & Name of the District & Total No of the Blocks & Infanticide Blocks & Female Infanticide Deaths \\
\hline 1. & Dharmapuri & 18 & 14 & 1199 \\
\hline 2. & Madurai & 21 & 19 & 571 \\
\hline 3. & Salem & 35 & 28 & 1033 \\
\hline 4. & Thiruvannamalai & 18 & 2 & 2 \\
\hline 5 & Dindigul & 14 & 14 & 11 \\
\hline 6. & Villupuram & 22 & 5 & 177 \\
\hline 7. & North Arcot & 20 & 9 & 01 \\
\hline 8. & Perambalur & 10 & 01 & 3 \\
\hline 9. & South Arcot & 13 & 1 & 3 \\
\hline 10 & Pudukottai & 13 & 1 & 69 \\
\hline 11 & Periyar & 20 & 4 & 13 \\
\hline 12 & Karur & 8 & 5 & 11 \\
\hline 13 & Thiruchirappalli & 14 & 03 & 01 \\
\hline 14 & Chengai & 27 & 01 & \\
\hline
\end{tabular}

Unless the Government launched effective intervention programme for empowering women, it is doubtful whether this practice can be prevented. There is a need for a multi pronged approach to stop the victimization of a girl child at the hands of the prevailing socio-economic system. Only a change in the status of a girl child the way for equal rights for 
women.

\section{Child Marriage}

The second social evil that persisted in society was child marriage. Dr. Annie Besant had a great regard for the Hindu custom of marriage and the ideal of this samskara - which she said, did not exist anywhere in the world. But this system lost its significance as well as validity because of the introduction of child marriages in India in the later periods of history due to various reasons. So, she said 'there is no ideal of marriage anywhere known which is more exquisitely beautiful than the Hindu ideal but it is trampled in the mud'. Girls were married at very young age i.e. between the ages of one to ten years and sometimes less than a year leaving no opportunity for them to improve their physical or mental health. Early marriage could adjust herself to her husband and his relations as well as to the new setup. But one of the abuses of this custom was that the wife lacked the knowledge of a married life and its responsibilities. The life in the new environment became miserable as the mother-in-law and other relations used to torture her. The girl child thus underwent suffering right from her birth, as a female child, as a child wife as a child-mother and very often as a child widow.

Child marriage means children were married even before they attained maturity, mentally and physically. Even infants below one year were married and parents of the bride and bridegroom would look after their children till they attained maturity. Normally the parents were in a hurry to marry off their daughter at an early stage and in some cases, even before the female child cause out of the womb of her mother.

In the case of child marriage, the victim was the female children because they were given in marriage to matured men. The parents of the female children normally kept them in their house till they attain puberty. During the course of time, the girls used to visit their husband's house and the husbands too visited the bride's house but no sexual intercourse would be allowed till the girl attained puberty.

The minimum age recommended by Menu for a girl being given in marriage was eight years. Husbands must be matured enough for running the family and have the capacity to shoulder the responsibility of the family. Vedas kept silent on child marriage. The great epics, Ramayana and Mahabaratha, were silent about child marriage and their heroines. Sita and Darupathi were married after attaining maturity. The Sangam literature gives limited reference to the existence of Child marriages. For instance, 12 year old Kannaki, the heroine of Silpathikaram, was married to 16 year old Kovalan. Child marriage received its momentum during the medieval period when the Muhammadans the country. Their invasion included plundering the country which resulted in a lot of social disorder and communal chaos.

\section{Causes}

Muslim invasion was one of the causes for Child marriage. Parents of female children could not save them from the hands of Muslim invaders who used to ravish the modesty of women and girls and kidnap the young girls for their sexual pleasure.

Another reason was that girls might fall into the hell of immoral life due to sexual impulse due to their age and this indulgence would cause illegal pregency and childbirth against these possible dangers, keeping a matured girl for long was a burdensome task to the parents. Hence they would like to marry their girls at an early age to avoid unhappy consequences. The most important cause for child marriage was dowry problem. Parents of the girls had to find a suitable husband at any cost. Talented and suitable bridegrooms were purchased by the bride's party and it caused further hardship to the bride's parties. 
The Hindu Law did not prohibit polygamy during the $19^{\text {th }}$ Century. Peculiar incidents such as a 40 year old man marrying a two year old girl were not uncommon in Tamilnadu. Brahmins, the Guardians of Hindu system and authority over the lower class, practised a system of bride price by which the bride groom had to give a considerable amount to the bride's father for the consideration of marriage. Parents wanted to reduce their burden by sending away their girl children in the name of marriage and they did not like to shoulder any further responsibility of their married daughters. Hence the parents hesitated to accommodate their married daughter driven out by their husband's family members. Such deserted child-wives became destitute and vagabonds of whom a considerable number of them became prostitutes. In $1881,21 \%$ of Hindu women were widows and around two percent of them had become widows before they attained puberty.

The right of the husband over his wife was immeasurable. They missed no opportunity to utilize their wives in all possible means. The consent of girls for sexual matters was not considered and in majority of ages, child-wives were raped by their husbands. In many instances, young innocent girls were killed for not yielding to the sexual impulses of their husbands and many girls died during forced sexual intercourse. Such unnatural events occurred due to the tenderness of girls and the over age of husbands who were not 20 or 25 years older than their wives.

Child-wives became the child mothers shortly and in many cases, pregnant girls perished during delivery. Child mortality was also very high and many newborn children died at the time of their birth itself. The health of both the mother and the surviving newborn children was not sound.

This unequal marriage of old men marrying young girls, resulted in the death of old men, leaving behind their young widows who, in many cases, might not have reached the age of puberty. There was a double moral standard existing in society. When the husband died, whether young or old, the wife should not marry again but when the wife died, her husband could marry again. In order to reduce the attraction and to be identified as widows, their mode of dress and hairstyle were changed by forcing them to wear white dress and shave off their heads. They would not be allowed to wear costly dress and grow hair. For avoiding any kind of contact with men, they were kept under tight security. To put it in a nutshell, it could be stated that they were forced to live a saintly life till their death. In India, in 1881, there were $2,09,36,626$ widows below the age of fifteen.

This system blocked all the channels of development - physical, mental and even spiritual. It resulted in crushing the individuality of the child wife. Early marriage and early consummation curtailed the freedom and joy of girlhood. The practice of child marriage was responsible for the high rate of infant mortality. Fuller observes, "Of children born every year, only about half the number reached the age of thirteen years".

Several efforts were made by Raja Rammohan Roy and other social reformers to fight against this social evil. In Andhra Pradesh, social reformers like Kandukuri, Venkatarathnam Naidu and others had dedicated their lives to this cause.

\section{Sati}

Sati is a Sanskrit term, literally meaning a "virtuous wife" but historically it has acquired the meaning of self immolation by Widows. It was the practice of the wife cremating herself on the funeral pyre of her husband. Sati means dying or killing the widow of a deceased person, on the funeral pyre. When the husband died, the wife, irrespective of age, would be buried live in the grave of her deceased husband or burnt alive with the dead body of her deceased husband in the same pyre. 
Sati was not a case of murder until the British Government declared sati Abolished through legislative intervention. Sati was originally preferred by women themselves because voluntary termination of life was preferred to being ravaged by enemy forces. Sati was further valorised by the romanticized concept of chastity and time-honored tradition of considering wife as only an appendage of her husband and the death of her husband rendered her earthly existence meaningless.

Sati is crime of murder by pushing with religious fury, the victim-wife into the funeral pyre as the flames consumed the husband's corpse. The act of widows consigning themselves to flames is called Sati. A widow is looked down upon as a stigma and to avoid this sigma, a woman would prefer sati.

Sati keeps popping up in this Century through it occurrence in revivalist celebrations. ${ }^{24}$ In 1980 , there were three reported cases were seven in the State of Rajasthan alone. In 1983, three cases of Sati were reported. Apart from the revival of this barbaric practice. What is Symptomatic of the cultural mores is the attempt to build a temple to venerate Tani Sati Narayani Devi. The cult of Rani Sati has its origin in Rajesthan's Jhunjbunu District. There are temples dedicated to her in Calcutta, Bombay, Kanpur, Delhi and wherever there is a substantial Marwari Community.

\section{Child-Marriage and Enforced-Widowhood}

Child-marriage and enforced-widowhood together formed another social disability that encrusted Tamil society in the $19^{\text {th }}$ century. Widows consisted of two types: 1) Child widows and 2) Adult Widows. It was the problem connected with the adult widows which drew the attention of the social reformers and the government. Widows who were spared from burning flames in the wake of statutory abolition of Sati in 1829, had to be given in re-marriage, but they were reluctant to have remarriage, as it was against the established Hindu custom of one-time marriage only for a woman. They said, "We are born once, we marry once and we die once'. As S.Rajalakshmi points out, the widows experienced the same humiliation in the Sangam period as they did in the Vedic period. Purananuru points out those widows had to remain unadorned and get their heads tonsured. Child-marriage in many cases led to early child-widowhood. It was the problem connected with the remarriage of the child-widows that drew the attention of the social reformers and the Government. Brahmins had their children married between the ages of 6 and 7 which accounted for the increase in the percentage of widows.

The main cause of the early marriage was due to scriptural injunctions. Manu says that "a man of thirty should marry a girl of twelve and a man of twenty-four, a girl of eight”. As per the Census of 1881, the total number of Hindu girls married in the Madras Presidency was 157,466 and the total number of widows in the same year (1881) was 5621. Similarly, the Census of 1891 for the Madras Presidency showed that the total number of married girls aged between 1 and 9 years was 166,544 as against 157,466 of the Census of 1881 and that those between 4 and 9 years were 988 and that those between 4 and 9 years were 4147, making a total of 5135. Thanks to Ishwar Chandra Vidyasagar (1820-1891) of Calcutta, the Father of the Widow Re-Marriage Movement in India, the Widow Re-Marriage Reform Act No.XV of 1856 was passed which declared that no widow re-marriage should be declared illegal and that no issue should be declared illegitimate on the ground that the woman had been previously married or betrothed to another person at the time of such marriage.

The Widow Re-marriage Reform Act marked a milestone in the women's march towards their emancipation, as the Government accorded legal sanction to widow re-marriage. The grateful women of Calcutta perpetuated Vidyasagar's memory by getting imprinted on the borders of their saris the first line of a Bengali song, the English rendering of which 
read: "May Vidyasagar live long." But, the act had little effect in Madras as the widows did not come forward for remarriage. ${ }^{31}$ Following the enactment of the Widow Re-marriage Reform Act in 1856, various widow re-marriage associations such as the Widow Re-Marriage Society (1873), the Madras Hindu Widow Marriage Association (1874), the Hindu Women's Re-Marriage Association (1882) and the Madras Hindu social Reform Association (1892) were started.

Compared to the Anti-sati Act passed in Tamil Nadu in 1830 by which Sati disappeared completely from Tamil Nadu including Tanjore district, its epicentre, the impact of the Widow Re-marriage Reform Act of 1856 was not noticeable. The result was that widows continued to suffer. Only in the $20^{\text {th }}$ century, the progressive social policies adopted by the Justice Party Government and the Self-Respect Movement spear-headed by Periyar E.V.R., led to the acceptance of the widow re-marriage concept in Tamil Nadu. At the far end of the $19^{\text {th }}$ century, the Madura Mail wrote: "Social Reform is slowly making headway among our people and there has been a distinct step towards progress." Social Reform is engaging the attention of our English-educated Countrymen." But, caste and economic inequality retarded social progress.

Men did not like the existence of widows in their house because of their degraded life as well as the inauspiciousness of their existence. Hence they wanted to do away with them in the initial moment of their widowhood itself. Another reason assigned to it was that young girls married to old men used to poison their aged husbands and lived with young men illegally. The fabulous wealth of rich old people attracted the attention of parents of young girls who married their daughters to such old men. The girl wife, along with her parents would poison her husband and enjoy the wealth of her husband. In order to protect the lives of the old men from their young wives, the male members formed the rule that the wife should die when her husband died.

Unwilling widows were also forced to abide by the custom. Unwilling widows were also forced to abide by the custom. The widow was administered intoxicating drugs to get her consent and remove the fear of death. In 1829, Lord William Bentinck, the Governor Gerneral of India abolished sati by Regulation No XVII of 1829. Rajaram Mohan Ray supported Bentinck and collected support from the elite public. In Madras Stephen Rumbold Lushington, the Governor of Madras, took the initiative to abolish the practice of sati by the Regulation of 1830. The famous Pandit Iswar Chandra Vidyasagar, the learned Principal of a Sanskrit College, induced the Government to introduce a bill advocating Widow Remarriage. At last, on $17^{\text {th }}$ November 1855, Grant a member of the Governor-General in Council introduced the Hindu Widow Remarriage Bill.

\section{CONCLUSIONS}

The Post-Independent India various legislations enacted the Legislative Assembly and the Indian Parliament. In being of independent India the women positions also highly developed Raja Ram Mohan Ray, Iswarchandra Vidyasagar, Magrant Cussions, Mother Therasa, Ammu Swaminathan, Lalitha Rajagopalan, Noorzahan Razak, Anjugam Ammaiyar, Dr.Dharmampal Ammaiyar, Sathiyavani Muthu, Mani Ammaiyar, Movaloor Ramamirtham Ammaiyar, Dr.Muthulakshmi Reddy, Sivagami Ammaiyur had given good contribution to developing the women's status.

The $73^{\text {rd }}$ Amendment of the Indian constitution provides for me-one third reservation for women in the Panchayats. It has led to an upsurge of women in the political field. At the present, there are many women representatives elected in the legislative assembly and social government. Thus can be said that, though there are many legislative and constitutional provisions covering almost all aspects of the life of women, yet the main concern is that after all this legislative exercise, what is required is that after this legislative exercise what is required is the implementation of laws in 
the true spirit so that women can enjoy equal rights and status as that man.

Since independence, the Government of India has passed several legislative acts which greatly improves the legal status of women. The Hindu Succession Act of 1956, which gives all women of India for the first time in the history of the country full and absolute ownership over everything which they inherit. This act also gives women greater rights of inheritance than they have ever before enjoyed. For many hundreds of years, the only women to inherit from their father were brotherless daughters, and it was not until the $13^{\text {th }}$ century AD., that most jurists recognized the widow's right to inherit her deceased husband's property in the absence of son's or grandsons. The legislation of 1956 is given equal inheritance rights to a man's widow, his surviving sons and daughters, and his mother to the exclusion of their heirs.

Some of the eminent social reformers are Moovalur Ramamirtham Ammaiyar, Ambujammal, Cuddalure Anjalai Ammal, Dr. A. Dharmmabal, Sister Subbalakshmi, Manjubhashini, Muthulakshmi Reddy, Ruckmini Lakshimipathy and others. The emancipation of women and the organizations formed to work for the uplift of women. The main focus of the activities in the Women's India Association towards social reforms pertaining to women, especially social legislations. The first section deals with the measure taken up for the eradication of the evil of Child Marriage. The other sections are respectively about the abolition of the devadasi system and the suppression of immoral traffic on women and children. They were the worst system which ruined the life of the women in the state.

\section{REFERENCES}

1. Lina Gonzales, Women and Human Rights (New Delhi: A.P.H. Publishing house 2001) p.134.

2. Wilson John, History of the suppression of Infanticide in Western India (Bombay: Smith Taylor and co, 1955) p.165.

3. Journal of Empowerment of Women (XXXII No.17, April 26- May 2, 1997)

4. J.A, Dubies Abbe., Hindu Manners, Customs and Ceremonies (London: Clarendon press, 933(pp.73-77).

5. Browne, Infanticide and its Origin (London: W.H Allen and co, 1957) p.66

6. J.A. Dubies Abbe., Hindu Manners, Customs and Ceremonies(London: Clarendon Press, 1933)pp.73-74

7. A.S.Panchapakesa Ayyar., Kovalan and Kannaki: the story of the Silapathikaram(Madras: Alliance company, 1947)p.78.

8. .V.A. Smith., History of History, (New Delhi: Vikas Publishing House, 1968), p. 185

9. Statistics Report (UNICEF: 1975)p 319.

10. National Family Health Survey (International Institute for Population Science, Government of India, 1973) p.61.

11. S. Chandrasekar, Factors Affecting Age and Marriage and birth in India,( Journal of Quantitative Economics,2010) p.43

12. Whiting Alex, Child Marriages: Causing and Impacts( New Delhi: Alpha publisher, 1991)p.143.

13. V.A. Smith, History of India (New Delhi: Vikas Publishing House, 1968) p.185.

14. Catherine, Ashes of Immortality: Widow-Burning in India(Chicago: University of Chicago Press, 2009)p.161

15. Devagi, Indian Women (New Delhi: Ministry of information and Brocading, Government of India, 1975) p.191.

16. R. Sudaralingam, Politics and Nationalist Awakening in south India, (New Delhi: Asian Publishing House, 1974) p.325.

17. Mohan, Women and political participation (New Delhi: University Press, 1992) p.40

18. Legislative Acts of the Governors-General of India in councils, 1834-1861 (Calcutta: Tacker Spink and co, 1868) p 243. 
19. Legislative Acts of the Governors-General of India in councils, 1834-1861 (Calcutta: Tacker Spink and co, 1868) p 243.

20. M.Sundar Raj., Prostitution in Madras, a study in Historical Perspective (Delhi:Saffron publisher, 1993)P.133.

21. Radha, The History of Doing: An Account of Women's Rights and Feminism in India (New Delhi: Zipra Press, 1993) p.132.

22. Abubakar, Ghazali Bello. "Tidal Phase of Democratic Transition in Tunisia, a Comparative Analysis with Taiwanese Democratization Process." IASET: Journal of Humanities and Social Sciences (IASET: JHSS) Vol. 3, Issue 1, Jan - Jun 2017; $5-22$

23. Abubakar, Ghazali Bello. "Tidal Phase OF Democratic Transition In Tunisia, a Comparative Analysis with Taiwanese Democratization Process." International Journal of Humanities and Social Sciences (IJHSS) ISSN (P): 2319-393X; ISSN (E): 2319-3948 Vol. 6, Issue 6, Oct - Nov 2017; 29-34

24. Katz, Yaron. "Social Media Is Powerful, but Can It Change Policies of Institutionalized Organizations Such as the Israeli Army?." International Journal of Humanities and Social Sciences (IJHSS) 6.6 (2017): 29-34. 